\title{
A First Glance at Albert the Great's Teachings on Analogy of Words
}

\section{BRUNO TREMBLAY}

Université Laval

Although any fair-minded reader will readily admit that Albert the Great was surpassed in solidity and clarity by his most famous pupil, Thomas Aquinas, his writings are generally of a richness that can be challenged only by a small number of philosophers. There is much to learn from Albert's works, whether one's interests are philosophical or merely historical. It is certainly no exaggeration to claim that he always provides a wonderful opportunity to reflect on philosophical matters, if only by the questions that he likes to raise, however unsatisfactorily he may sometimes answer them. My purpose here is to examine his teachings on a problem that has aroused a considerable amount of interest among the modern interpreters of Aquinas: analogy of words. What Albert the Great said on analogy of words, however, suffers along with most of his works, especially those concerning logic, from being little known.

My goal in this article is very modest: to point out and bring to light what appear to me to be Albert's two most fundamental texts on analogy of words. By "most fundamental texts," however, I do not necessarily mean those that touch all the aspects of this complex question, nor those that represent his final word thereon, but those that should be read before any others because they establish clearly enough to what science the study of analogous words belongs, first and foremost, and also provide us with the very first determination of the question within that science. Since so little attention has been given to them so far, I think that the following consideration, however brief and superficial it might be, is worthwhile. This article should not, therefore, be seen as a complete and definite statement of Albert the Great's doctrine but rather as an indication of what should be, in my view, the point of departure of any such statement.

Yet the narrow scope of the present article should not lead us to think that the work can be very easily and rapidly done, and this for three reasons. The impediment that is most immediately noticed is, of course, Albert himself, especially the obscurity and imprecision of his Latin, and perhaps

I am indebted to my wife, Cynthia Tremblay, and to Professor Warren Murray for their kind and numerous suggestions concerning my use of the English language throughout this paper. 
of his thought as well. Indeed, we see that he is often navigating in troubled waters, and it is not always easy to determine exactly what he is saying and why he is saying it. Another reason, more fundamental, is related to the subject itself, analogy of words being a problem of much greater difficulty than it seems at first sight. Finally, one can hardly rely on anterior works: I know of only one somewhat systematic study on analogy based on Albert's writings, and it lies within a strictly theological context. ${ }^{1}$

Two texts constitute the main object of the present consideration: Super Porphyrium De V universalibus, tract. 1, cap. 5, and De praedicamentis, tract. 1, cap. 2 and $3 .^{2}$ A few other texts are also considered and referred to, but always with respect to these two.

\section{ANALOGY OF WORDS AS A LOGICAL MATTER}

That for Albert the Great analogy of words is first and foremost a logical matter can be seen in two ways. The first one is indirect and is consequent on his taking such a position. A quick perusal of all of his texts where this topic is treated will suffice to convince us that the only passages that discuss analogy of words for its own sake, and not as an element of the solution to some other problem (whether theological, natural, moral, or even logical), are to be found in his commentary on the Organon. Indeed, aside from a few remarks on the subject in his commentaries on the De divisione and on the Sophistical Refutations, he formally tackles this question only in the above-mentioned works, that is, in his general introduction to logic (preceding his commentary on the Isagoge, properly speaking) and in his commentary on Categories, 1a1-12. Another and more interesting way in which

1. H. Lyttkens, The Analogy between God and the World. An Investigation of its Background and Interpretation of its Use by Thomas of Aquino (Uppsala: Almquist \& W. Ksells boktryckeri, 1952). The part devoted to Albert the Great is on pp. 153-163. Among the many passages to which the author refers, none comes from a logical treatise; in fact, all but one (Metaphysica, lib. IV, tract.1, cap. 3) are from theological works. It is only honest to say, however, that the author, as the title of the book indicates, is more interested in the analogy between realities than between meanings of words. Francis Ruello, in his Les "noms divins" et leurs "raisons" selon Albert le Grand commentateur du De divinis nominibus (Paris: Vrin, 1963), also touches on the problem of analogy but in an even less systematic fashion. One should also mention E. J. Ashworth's "Analogy and Equivocation in Thirteenth-century Logic: Aquinas in Context," Mediaeval Studies 54 (1992): 94-135, and A. de Libera's "Les sources gréco-arabes de la théorie médiévale de l'analogie de l'être," Les études philosophiques (1989): 319-45, where the texts that I consider are very briefly alluded to.

2. The first tractatus of the commentary on Porphyry's Isagoge has been separately edited by J. Blarer under the title "De antecedentibus ad logicam," Teoresi 9 (1954): 177-242 (hereafter referred to as Blarer). When referring to the remainder of the work, I use, as for the De praedicamentis, the conventional Borgnet edition of the Opera omnia (Paris: Vivès, 1890), vol. 1 (hereafter Paris). 
the logical nature of this question can be made manifest is based on Albert's teachings themselves, especially in his general introduction to logic. I now devote some time to this text.

Following his Arabic masters, ${ }^{3}$ Albert thinks it suitable to present some considerations on words in his general introduction to logic, both on what they are and on the way in which they signify. The reason for these general and introductory considerations on words, he says, is rooted in the very nature of the subject of logic, namely, things as they exist in the mind of the one progressing from the known to the unknown: "Quia autem logica omnia considerat prout sunt in anima sive intellectu eius, qui quaerit per notum sibi venire in notitiam ignoti, gratia horum considerat de voce significante ad placitum et quid et qualiter significet."4

Logic, in other words, considers properties that attach to things only in the process of knowing, more precisely to things that we already know when we start from them to know things we did not know before. 5 These properties, which are used in an almost instrumental way when embodied in such and such a nature, ${ }^{6}$ are studied by logic to help us ensure a better and safer passage from the known to the unknown-something that we do naturally but imperfectly. ${ }^{7}$ For example, the nature of animal as known, when compared to that of man, acquires a certain property, namely, that of being a genus, so that we can know what a man essentially is, although that nature is common to others species as well. Now the intellect cannot use these purely intellectual properties to serve its purpose unless the nature they attach to is in some way incarnated in its vocal, and therefore sensible, sign: sine sermone designativo procedere non potest ad notitiam eius, quod ignotum est. ${ }^{8}$ To take the same example, when we partially grasp what a man is by means of the known nature of animal, we do so, whether by inner or outer speech, through its sensible sign, that is, the word "animal." Albert the Great applies that general principle throughout the study of the whole of logic, for example, in the type of study of the "predicables" that constitutes the science of the ten categories or "predicaments":

3. See Avicenna, Logyca (Venetiis, 1508), fol. 5v; Algazel, Logica Algazelis, maneria prima, ed. C. Lohr, Traditio 21 (1965): 223-90 (hereafter Lohr).

4. De antecendentibus ad logicam, cap. 5 (Blarer, p. 215): "Logic considers all things in as much as they are in the soul or the intellect of the one who seeks to come to the knowledge of the unknown through what is known to it [the intellect]. Because of that and by interest for those things [logic] considers, about the vocal sound that signifies by convention, what it signifies and how it signifies . . ."

5. De antecedentibus ad logicam, cap. 2. The consideration of some of these properties-for example, definition and, above all, argumentation-being the end of that of the others, the whole subject of logic can be identified with only one or a few of these properties. See De antecedentibus ad logicam, cap. 4.

6. De antecedentibus ad logicam, cap. 7 (Blarer, p. 232); Analytica Posteriora, lib. I, tract. 1, cap. 3 (Paris, vol. 2, p. 8B).

7. De antecedentibus ad logicam, cap. 1 (Blarer, pp. 194-95).

8. De antecedentibus ad logicam, cap. 4 (Blarer, p. 210). 
Quia autem jam in antecedentibus ad logicam probatum est, quod ad scientiam ignoti per cognitum non devenitur, nisi per dispositum sermonem ad significandum, sive homo inquirat apud seipsum per interius dispositum sermonem, sive inquirat apud alium per sermonem exterius prolatum, sequitur de necessitate quod ordo praedicabilium non potest determinari, nisi secundum quod sub voce habet praedicabile designari. ${ }^{9}$

This is why these logical properties, primarily properties of concepts or things as known, are considered and defined by Aristotle and many of his followers as they also exist in the vocal signs of the concepts. The philosopher has set the tone, so to speak, in his introduction to the Peri Hermeneias, certainly the most universal of all his logical introductions. Indeed, in his preliminary remarks (16a9-18), preceding his treatment of noun, verb and statement, he clearly indicates that four of the most fundamental properties of things as known, namely, complexity and incomplexity and truth and falsity, are also to be found in some way in the vocal signs of the concepts, to which concepts these properties are primarily attached:

Just as some thoughts in the soul are neither true nor false while some are necessarily one or the other, so also with spoken sounds. For falsity and truth have to do with combination and separation. Thus names and verbs by themselves-for instance 'man' and 'white' when nothing is added-are like the thoughts that are without combination and separation; for so far they are neither true nor false. ${ }^{10}$

Thus, the definitions of logical entities given by Aristotle and invariably accepted by Albert will often be definitions of kinds of vocal sounds, not as such but inasmuch as they are signs of things as known, for example, the definition of enunciation: a speech wherein are to be found truth or falsity, ${ }^{11}$ and of definition: a speech that manifests or says what a thing is, ${ }^{12}$ and so forth.

Let us now go back to Albert's general introduction to logic and to the chapter he devotes to vocal sounds. First, he enumerates five ways in which a word is said to signify something, a list that has no equivalent in Aristotle and is, as far as I know, peculiar to his Arabic sources. The remainder of the

9. De praedicamentis, tract. 1, cap. 1 (Paris, vol. 1 pp. 149B-150A): "Since it has already been proven in the De ancecedentibus ad logicam that one cannot arrive at the knowledge of the unknown through the known unless some word [sermo] has been laid down to signify - whether one tries to know by oneself, through an inner word, or one tries to know by somebody else, through an outer word-it follows necessarily that the order of the predicables can be determined only in as much as the predicable is signified by a vocal sound."

10. Aristotle, Peri Hermeneias, 1, 16a9-18; all references are to J. L. Ackrill's translation (Oxford: Clarendon Press, 1963).

11. Aristotle, Peri Hermeneias, 4, 17a2-4.

12. Aristotle, Topics, VII, 3, 153a15-16. 
chapter presents four divisions of dictiones according to some of their properties: (1) vocal sounds that signify conventionally may be complex (like an argument, a statement, or a definition) or incomplex (that is, words in the sense of "elements of speech"); (2) words may be universal or particular; (3) words may be nouns or verbs; (4) words may be univocal, "diversivocal," "multivocal," equivocal, or analogous. Before looking at the last group, it is interesting to see how Albert introduces the first three because it confirms what was said earlier about the subject of logic and its consideration of vocal sounds that signify conventionally:

Complexio autem et incomplexio non accidunt rei secundum quod res est nec etiam voci secundum quod est vox, sed accidunt voci secundum quod refertur ad intellectum, simplicem vel compositum. ${ }^{13}$

Adhuc autem vox, secundum quod refertur ad intellectum eius, qui quaerit invenire ignotum per notum, habet quod dividitur in commune sive appellativum sive universale et proprium sive singulare. ${ }^{14}$

Adhuc dictio sive vox significativa et articulata non ex hoc quod refertur ad rem designatam, sed ex hoc quod est in intellectu quaerentis ignotum scire per notum habet quod quaedam ipsius est nomen, quaedam autem verbum. ${ }^{15}$

All of these are properties assigned to words not in virtue of themselves, nor in virtue of what the real things are that they indirectly signify, but as signs of what happens to the real things as we know them and use them to know something else. For example, words and the natural things that surround us are all singular and sensible beings. ${ }^{16}$ However, since we can represent real things to ourselves either in their singularity or in what they have in common with other things, and since words signify things only through our representations, ${ }^{17}$ words as signs are also universal or singular. Those two properties of vocal sounds thus belong to the consideration of logic, as does any like property. ${ }^{18}$

13. De antecedentibus ad logicam, cap. 5 (Blarer, pp. 216-17): "Complexity and incomplexity do not belong to the thing in as much as it is a thing, nor to the vocal sound in as much as it is a vocal sound, but they belong to the vocal sound in as much as it refers to the concept, whether simple or composite."

14. De antecedentibus ad logicam, cap. 5 (Blarer, p. 217): "Again the vocal sound, in as much as it refers to the concept of the one who tries to discover the unknown through the known, is divided into common or appellative or universal and proper or singular."

15. De antecedentibus ad logicam, cap. 5 (Blarer, p. 219): "Some words (or vocal and articulated sounds) are nouns, and some are verbs. Now, this is not due to the fact that they refer to the signified thing, but to the fact that they are in the intellect of the one seeking to know the unknown through the known."

16. De antecedentibus ad logicam, cap. 5 (Blarer, pp. 217-18).

17. Aristotle, Peri Hermeneias, 1, 16a1-19; Albert the Great, Peri hermeneias, lib. I, tract. 2, cap. 1-2.

18. As for the property of being a noun or a verb, that seems to belong rather to grammar; see Albert's Peri Hermeneias, lib. I, tract. 2, cap. 4-5 and tract. 3, cap. 
The last group of properties of vocal sounds, of greater interest to us, is an obvious reminder of the beginning of Aristotle's Categories, where univocation and equivocation (in which what we call analogy seems also to be included) are briefly discussed. As we know, the Greek commentators ${ }^{19}$ added two more members to this division: ć $\tau \varepsilon \rho \omega ́ v v \mu \alpha$ (multivoca) and $\pi \mathrm{o} \lambda$ -

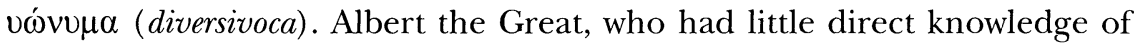
those commentators, was nevertheless aware of this "completion" through diverse sources like Boethius, ${ }^{20}$ John of Damascus, ${ }^{21}$ and the Arabic philosophers mentioned above. This group is introduced exactly in the same way as the others:

Adhuc autem voci significativae ad placitum, secundum quod est in intellectu quaerentis ignotum scire per notum, accidunt quinque, scilicet quod sint univoca quaedam ex ipsis et quaedam diversivoca, quaedam autem multivoca, quaedam autem aequivoca et quaedam analoga sive proportionata, quae Arabes vocant convenientia. ${ }^{22}$

Since analoga ... sunt media inter univoca et aequivoca, ${ }^{23}$ I change Albert's order of enumeration and see first how he describes "diversivocal" and "multivocal" words and then equivocal, univocal, and analogous words. "Diversivocal" words are defined as follows: "Diversivoca sunt diversa nomina unius et eiusdem rei secundum substantiam, eo quod instituens nomina illa diversis rei proprietatibus in instituendo fuit affectus, ut ensis, mucro, spatha, gladius, sica, framea, et huiusmodi." 24 Diversivoca are different words of substantially one thing (that is, one nature or essence, and not one singular being), what we would call today synonyms. Albert's examples, taken directly from antiquity, might not be extremely familiar to twentieth-

$1-2$, where he explains how the logical point of view on nouns and verbs differs from the grammatical one, leading to different definitions.

19. See, for example, Simplicius, In Aristotelis Categorias Commentarium, 22, 22-33, C. Kalbfleisch, ed. (Berlin: Reimer, 1907).

20. In Categorias Aristotelis, 163D-164A; in Patrologiae cursus completus (Paris: Migne, 1847), vol. 64.

21. Dialectica (Latin version), cap. 17-18; O. A. Colligan, ed. (St. Bonaventure, N.Y.: Franciscan Institute, 1953). See Albert the Great, De praedicamentis, tract. 1, cap. 3 (Paris, vol. 1, p. 157A).

22. De antecedentibus ad logicam, cap. 5 (Blarer, p. 219): "Vocal sound that signifies by convention, in as much as it is in the intellect of the one seeking to know the unknown through the unknown, happens to be five [things]: some of them [sic] are univocal, some diversivocal, some multivocal, some equivocal and some analogous or proportionated (which Arabs call 'related')."

23. De antecedentibus ad logicam, cap. 5 (Blarer, p. 220). See Logica Algazelis, maneria prima, 5 (Lohr, p. 246).

24. De antecedentibus ad logicam, cap. 5 (Blarer, pp. 219-20): "Diversivocals are different words of substantially one and the same thing, because the one imposing those words was influenced in his act of imposition by different properties of the thing. For example, ensis, mucro, spatha, sica, framea, and others of the same kind." 
century readers, who are not accustomed to designating swords with such a variety and richness of words. The definition corresponding to all these words, we are told by John of Damascus, ${ }^{25}$ is ferrum anceps.

The second property of this group is multivocatio. Multivoca are totally different words with totally different meanings, like "cat" and "constitution" or "horse" and "ass": "Multivoca sunt diversarum rerum diversa nomina, eo quod instituens diversis diversarum proprietatibus instituendo fuit affectus, ut equus et asinus." 26

The definition of univocal words is more relevant to our discussion, mainly because, as we see later, Albert tends to view analogous words as an imitation of univocal words: "Univoca autem sunt, quae a tali forma imposita sunt, ad quam omnium participiantium ${ }^{27}$ eam est respectus unus secundum rem et rationem, sine magis sive minus [variant reading: sine magis et minus]. Sicut animal participatur a speciebus animalium et homo participatur ab individuis, quae sunt sub ipso." 28

If I understand this rather ambiguous definition correctly, it means this: a word is univocal when the nature or form (forma) signified is said of things that relate to this nature (secundum rem) that they participate in and to its definition (secundum rationem) in exactly the same way (respectus unus). Albert then adds this somewhat puzzling remark: sive magis sive minus, "whether they participate in it more or less," or according to another manuscript: sine magis et minus, "without one participating in it more and another participating in it less." In my opinion, both variants are possible: they both find confirmation in other texts of Albert and of his masters; 29 in any case, they do not contradict each other, despite the appearance of doing so. This question is of a certain interest to us because answering it will help us see how univocation-and analogy, indirectly and by way of preparation-is for Albert a logical matter.

How could Albert possibly say that things named by a univocal word may more or less participate in the nature, or res, signified by that word? In

25. Dialectica, cap. 17.

26. De antecendentibus ad logicam, cap. 5 (Blarer, p. 220): "Multivocals are different words belonging to different things, because the one imposing them was influenced in his act of imposition by the different properties of the different [things]. For example, horse and ass."

27. The text reads partecipiantium, which I presume is a typographical error.

28. De antecedentibus ad logicam, cap. 5 (Blarer, p. 219): "Those are univocals which have been imposed starting from a form that is such that all those participating in it are related in one way to the thing and to its definition (whether they participate in it more or less [other reading: without one participating in it more or less]), as [the form] animal is participated in by the species of animals and [the form] man is participated in by the individuals that are under it."

29. As for sine magis et minus, see Logica Algazelis, maneria prima, 5 (Lohr, p. 245), after which Albert's in troductory chapter on vocal sounds is modeled, and, more conclusively, Albert's De praedicamentis, tract. 1, cap. 2; for sive magis sive minus, see Albert the Great, Metaphysica, lib. IV, tract. 1, cap. 3 (Monasterii Westfalorum: In aedibus Ashendorff, 1960, vol. 16, p. 163, 1l. 42-45); and Aristotle, Topics, I, 15, 107b13-18. 
saying so, he would have in mind Topics, 107b13-18, where Aristotle explains how to discover whether a word used in a discussion is equivocal or univocal. One of the ways to do so, as in the case of alba when said of two different things, is to ask if they are equally albae or if one is more alba than the other: if such is the case, then the word must be univocal; but if it is not possible to answer the question, that is, if the named things cannot be compared, then there must be equivocation. Both situations occur with alba when said of a voice and of a garment, on the one hand, and of snow and of a garment, on the other hand:

Et ideo si in illa forma comparari non possunt ea quae sub eadem voce figurantur, erunt proculdubio aequivoca, et multipliciter dicta, ut alba vox et vestis alba non comparantur in albedine: quia vox nec magis nec minus, nec aeque alba dicitur ut vestis . . . . omne univocum in forma quam significat nomen, comparabile est, quod eamdem formam et nomen idem participat: aut similiter ${ }^{30}$ (hoc est, secundum aeque) dicetur, ut homo et asinus animal: aut alterum dicetur magis vel minus, ut nix dicitur albior veste. ${ }^{31}$

However, this is an appeal to reality and to the way in which the signified nature or form is realized in the singular things, and not merely to what the word signifies. To take the same example: "white," when said of some garment and of snow, means exactly the same thing; that is, the intentio or known nature is the same and is defined in the same way, even if on the level of reality snow might be whiter than the garment in question. Albert speaks in such a way when he discusses the question of whether a specific difference "suscipit magis et minus: illae quidem differentiae quae per se sunt . . . non suscipiunt per intentionem magis et minus." 32

Logically speaking, then-that is, on the level of the intention signified-things named univocally participate equally in the signified nature, and it is accidental to logical univocation whether in reality one participates in it more than the other or whether they in effect participate in it equally. What matters in logic is if things are "made equal" by intelligence in one tion.

30. Borgnet reads aut non similiter (Paris), which I presume is a textual corrup-

31. Topica, lib. I, tract. 4, cap. 6 (Paris, vol. 2, p. 285B): "and therefore if those that are signified by the vocal sound cannot be compared as to that form, they without a doubt will be equivocal, and said in a multifold way. For example, a white [clear] voice and a white garment cannot be compared as to their whiteness, because in comparison to the garment the voice is not said [to be] more, less or equally white.... [however], every univocal that participates in the same form and in the same word can be compared as to the form signified by the word, whether [that word] is similarly, that is to say equally, said (as man and ass [are said to be] animals), or one is said [to be] more or less [so] (as snow is said to be whiter than a garment)."

32. Super Porphyrium De V universalibus, tract. 5, cap. 2 (Paris, vol. 1, p. 85B); my emphasis. 
common nature. ${ }^{33}$ Things named univocally, then, participate in one nature defined according to one definition, without their participating in it more or less at the intentional level (sine magis et minus), no matter whether they do so on the real level (sive magis sive minus). Later, I point out another text where the same contrast between intention and reality is made, but in relation to analogy of words.

The description of equivocal words is a bit more surprising:

Aequivoca sunt, quando unum nomen diversis secundum rationem impositum est, eo quod una aliqua proprietas inventa in diversis affecit instituentes. Quae tamen proprietas non per unam rationem est in illis, ut canis, quod nomen est impositum latrabili et stellae caelesti et marino pisci propter unam proprietatem inventam in illis, quae est: omnia haec esse mordacia, cum tamen non una ratione mordacia sint. ${ }^{34}$

Those acquainted with Aquinas will be surprised to read this because he always interprets this classical example as a case of a word with two or more totally unrelated meanings, ${ }^{35}$ whereas Albert seems to see a link between them. For the latter, indeed, "dog" can mean a barking and terrestrial animal, a sea fish, or a star because those who imposed meanings on that word were influenced by some one property that exists in each of them: all bite. However, when we say that all bite and try to define what we mean by that, we give three different accounts or definitions (omnia sunt mordacia, cum tamen non una ratione mordacia sint). This description of equivocation seems to be pulling in two opposite directions: on the one hand, the community between those three things is purely nominal, but on the other hand, it influenced the word-makers to give them a common name. I think that Albert is right by saying that there is a reason why men applied this same word to those three things and that it is not the product of mere chance; however, the formulation of his explanation in this particular text is, to say the least, somewhat unsatisfactory. It remains to be seen if his commentary on Aristotle's Categories sheds more light on this problem.

33. To use an expression found in Aquinas, Scriptum super libros sententiarum, I, d. 19, q. 5, a. 2, ad 1; P. Mandonnet, ed. (Paris: Lethielleux, 1929); thereafter, Mandonnet ed.

34. De antecedentibus ad logicam, cap. 5 (Blarer, p. 220): “There are equivocals when one word has been imposed on [things] that are different as to their definition, because those imposing it are influenced by some one property found in different [things]. Yet, this property is not found in them according to one definition. For example, the word "dog" has been imposed on the one that can bark, on a star and on a sea fish, because of some one property that is found in them, namely that all bite, though not according to one definition."

35. See, for example, In libros Metaphysicorum Aristotelis expositio, lib. IV, lect. 1, n. 535 (Roma: Marietti, 1950). 
Here is what he has to say about analogous words:

Analoga autem sive proportionaliter dicta sive, ut Arabes dicunt, convenientia sunt media inter univoca et aequivoca, quae sunt imposita diversis secundum esse et substantiam per respectum ad unum, cui proportionantur, sicut ens, quod dicitur de substantia primo et principaliter et de accidente secundario, quia est aliquid substantiae vel entis principium, ut quantitas dicitur ens, quia est mensura entis, et qualitas dicitur ens, quia est dispositio entis. ${ }^{36}$

An analogous word is a word imposed on essentially different things with respect to something to which they are related, for example, the word "being" when applied to a substance and to a quantity. If we try to explain what we mean by "being" in each case, we will see that two different meanings are referred to. However, there is a certain unity between them because the meaning of the word as said of a quantity comprehends in itself what we mean by "being" when said of a substance: when we say that a quantity is a being we mean that it is a measure of being in the primary meaning of the word (that is, of a substance). In other words, there is some determinate nature to be found in each of the meanings, but in different respects.

This explanation shows us how analogous words differ from univocal words. In the light of this one text, however, it is hard to grasp what essentially separates the two. Albert ends his description of analogous words with a division, which, he says, is to be found in Averroes and Dionysius but is ultimately rooted in Aristotle, Metaphysics, 1003a33-b6.

Et hoc, ut dicit Averroes in Metaphysica sua et Dionysus, fit tribus modis, scilicet proportione ad unum subiectum ut ens et proportione ad unum efficiens actum, ut medicus dicitur vere medicus, qui secundum eam, quae in ipso est, medicinam operatur; et medicus dicitur idiota medicum per experta vel inexperta imitans in opere medicandi et non operans secundum eam, quae est in ipso sit, artem medicinae; et medicus dicitur instrumentum medicinae, per quod fit medicatio, ut clyster vel embrocha vel aliquid huiusmodi. Dicitur tertio proportione eiusdem finis ut sanum quod principaliter est in aequalitate complexionis animalium ${ }^{37}$ et est in cibo sicut in conservante eandem sanitatem

36. De antecedentibus ad logicam, cap. 5 (Blarer, p. 220): "Those that are analogous or said according to a proportion (or, as Arabs say, 'related') are intermediary between univocals and equivocals: they have been imposed on [things] that are essentially and substantially different in relation to some one [thing] to which they are proportionated. For example, 'being': it is said primarily and principally of substance, and secondarily of accident, because it is something of substance or a principle of being, as quantity is said a being because it is a measure of being, and quality is said a being because it is a disposition of being."

37. Blarer gives animalitum. 
et in urina sicut indicante et in aere vel loco sicut favente, et similiter est in aliis. ${ }^{38}$

Before looking at Albert's commentary on the Categories, it would be well to mention a problem that might arise upon the reading of Albert's conclusion to this general and introductory consideration of dictiones since it is apt to raise some doubt about the logical or nonlogical nature of the analogy of words. This is what he says, right after completing this consideration and before beginning a new chapter:

Haec autem omnia de logicis Arabum extracta sunt, eo quod haec conveniunt voci significativae et articulatae secundum quod per institutionem afficit intellectum eius, qui per notum certificare quaerit ignotum. Volumus enim, secundum consuetudinem quam in aliis, omnia quantum possumus ponere, quae ad illuminationem pertinent doctrinae. ${ }^{39}$

Albert had justified this lengthy consideration on vocal sounds that signify conventionally by the nature of the subject of logic. In his conclusion, however, he seems to justify it only by the fact that such sounds influence, through their conventional meanings, the one who seeks knowledge. The last sentence might confirm this interpretation. Indeed, it is Albert's habit to speak in terms of perfectio, ${ }^{40}$ bonitas, ${ }^{41}$ illuminatio, declaratio, or claritas $^{42}$ doctrine about the things that strictly speaking do not belong to the subject

38. De antecedentibus ad logicam, cap. 5 (Blarer, pp. 220-22): "And this, as Averroes says in his Metaphysics and [pseudo-]Dionysius, is done in three ways, that is to say: 1) in relation to one subject, as in the case of 'being'; 2) in relation to one effective act, as he is truly a medicus who has and acts in conformity with [the art of] medecine, whereas an ignorant man is also said [to be] a medicus who imitates him in the act of healing and does not have and act in conformity with the art of medecine, and an instrument of medecine by which the act of healing is performed, for example a syringe, an ointment, or something of that kind, is also said [to be] medicus; 3) thirdly, in relation to that same end, as in the case of healthy: it is found principally in the equality of humors of animals, and also in food in as much as it maintains health, in urine in as much as it is a sign thereof, in air or place in as much as it favours it, and likewise in other [things]." This text, as De praedicamentis, tract. 1, cap. 3 (Paris, vol. 1, pp. 152B-153A), makes it hard to believe, as Ashworth ("Analogy and Equivocation," p. 123) does, that Albert the Great treated sanum and ens in the same way.

39. De antecedentibus ad logicam, cap. 5 (Blarer, p. 222): "All that was extracted from the logical Arabic [treatises], because it has to do with the vocal sound that signifies and that is articulated in as much as it conventionnaly influences the intellect of the one seeking to know the unknown by the known. Indeed, we want, in conformity with the habit that [we took] in other [works], to lay down, as much as we can, whatever contributes to the illumination of the science."

40. Super Porphyrium De V universalibus, tract. 9, cap. 3 (Paris, vol. 1, p. 148B).

41. Super Porphyrium De V universalibus, tract. 2, cap. 3 (Paris, vol. 1, p. 20B). 
of the science but whose consideration might help introduce this subject and throw some light on it-or simply eliminate certain questions that might best be answered elsewhere but are resolved at once lest they distract the student. If illuminatio really has such a meaning here, then what exactly among the previous considerations does belong to logic and what does not? Certainly, everything in this consideration is not, strictly speaking, logical. The first division, as I have said, merely enumerates some meanings of the word "signification" rather than classifying words according to what happens to them as signs of what happens to things when known. Now, what about diversivocatio, multivocatio, univocation, equivocation, and analogy? We see that in his commentary on the Categories, Albert states that only the last three are a concern for the logician, which will confirm the logical character of the analogy of words and show that what he says at the outset of his introductory consideration on vocal sounds must be taken broadly.

There is another text, however, outside of his logical works-namely, in his second commentary on the Nicomachean Ethics-in which Albert points out that the analogy of words is a logical matter and in which way it is so. In the first book, Aristotle affirms that "good" is probably said in reference to many meanings. Following Aristotle's own suggestions, Albert briefly explains three ways in which "good" might be an analogous word and then adds,

Et quamvis omnia ${ }^{43}$ haec multiplicitas in bono possit inveniri, eo quod multa sunt bona, quia sunt a bono, et multa bona, quia ad bonum: tamen de his relinquendum est nunc. Certificare enim de ipsis proprium est magis alterius philosophiae. Si enim de communi loquamur secundum intentionem qua praedicatur de pluribus, logici est determinare multiplicitatem ipsius. Si vero loquamur de communitate rei, talis multiplicitas determinanda est a metaphysico: in quinto enim illius scientiae de hujusmodi tractatur. ${ }^{44}$

Analogous words, then, belong to logic inasmuch as their analogous character comes from the intentions that they directly signify and not from some real analogy between the things that they signify through the inten-

42. Summa theologiae, lib. I, tract. 1, q. 3, cap. 1, sol. (Monasterii Westfalorum: In aedibus Ashendorff, 1978), vol. 34, p. 10, 11. 78-87).

43. This word has to be eliminated or to be replaced by omnis.

44. Ethica, lib. I, tract. 5, cap. 17 (Paris, vol. 7, p. 82A): "Even though this multiplicity can be found in good-since many [things] are good because they come from the good, and many because they are for the good-, yet they have to be set aside for now, for treating those belongs to another [part of] philosophy. Indeed, if we are talking about the common [good] according to the intention that is said of many, treating this multiplicity belongs to the logician, but if we are talking about the commonness of reality, such a multiplicity has to be treated by the metaphysician. Things of this sort are indeed treated in the fifth [book] of that science." 
tions, that is, the forms or determinations of the real things as grasped and conceived by the intellect. As in the case of univocation, then, Albert warns us that when discussing analogous words, the logician must keep his attention on the way in which we conceive and know things and not, at least not as such, to the way in which things exist. 45

\section{UNIVOCATION, EQUIVOCATION, AND ANALOGY REVISITED}

In his commentary on Aristotle's Categories, Albert the Great gives a more detailed account of equivocation, analogy, and univocation than in his general introduction to logic. Because he is now commenting on Aristotle, however, he adopts a slightly different approach: things, and not words, are first said to have those logical properties, and analogy is no longer placed alongside equivocation and univocation; rather it is seen as a mode of equivocation.

As for the first point, I think that it makes little difference for Albert whether things or words are said to have these logical properties because, in both cases, such a way of speaking refers to the modus intelligendi: both things and their words have these properties only in virtue of the way in which we know things. The simple fact that he does not even bother to raise the question, as well as that within the very same commentary on Aristotle's few lines on univocation, for instance, he attributes this property to things and to words alternatively, only confirms this point. Often-and by this I mean not only in this commentary-Albert will say that logic considers things not as they exist in natura rerum but as they exist in our words. ${ }^{46}$ But as we already know, this gives only half the answer and might lead to a misunderstanding of Albert's conception of logic for anyone who has not read carefully enough the De antecedentibus ad logicam: logic studies things as named, but only inasmuch as words are signs of what necessarily happens to things when we know them. To say that logic studies purely intellectual properties is, of course, very abstract, and there is nothing surprising in the fact that a logician like Albert the Great prefers to discuss them through something more concrete and easier for us to grasp: that is, the real things that are their foundation or, more frequently, the vocal sounds that signify them.

Concerning the other difference, that is, the fact that in his De praedicamentis Albert places analogy within equivocation and not alongside it and

45. This extract from the Ethica could have enriched Ashworth's analysis ("Analogy and Equivocation," pp. 126-127) of Aquinas's well-known text Scriptum super libros sententiarum, Id. 19, q. 5, a. 2, ad 1, Mandonnet ed.

46. See, for example, Peri hermeneias, lib. I, tract. 1, cap. 1 (Paris, vol. 1, p. 375B), and Posteriora Analytica, lib. I, tract. 1, cap. 1 (Paris, vol. 2, p. 2B). 
univocation, it appears to me to be of little significance and is probably to be explained by the variety of Albert's immediate sources: Algazel, on the one hand, and Aristotle, on the other. Analogy being, as Albert said, an intermediary between equivocation and univocation, it can in fact be considered by itself, as a kind of equivocation, or as a kind of univocation, depending of which aspect of analogy one wants to emphasize. In fact, Albert considers that both analogy and equivocation decline from univocation, and in this sense Aristotle's order of enumeration (first equivocation and then univocation) is perhaps not Albert's best ally. Univocation, analogy, and equivocation are three types or modes of commonness of predication: the most perfectly common is univocation, whereas everything that declines from this perfection, whether analogy or equivocation stricte loquendo, is grouped under one general heading, equivocation large loquendo.

\section{Univocation}

After stating that it is only through a commonness of univocation that a predicable nature or form can be placed in a genus, Albert gives Aristotle's account of univocation: . . . et ideo diffinitur sic ab Aristotele quod univoca dicuntur quorum nomen commune est, et secundum nomen illud eadem est substantiae ratio sive diffinitio. ${ }^{47}$ Albert then explains each element of this definition, in accordance with traditional teaching. ${ }^{48}$ Aristotle, he says, speaks of univocals, using the plural rather than the singular form, because through a univocal word our intelligence unites the plurality or even infinity of reality; ${ }^{49}$ Aristotle also says dicuntur, and not sunt, to mark the fact that we are not here interested in what things are in themselves but in what things are due to our naming (and hence knowing) them: Et dicuntur univoca . . . ut res ipsa ad dici et ad sermonem referatur, quia aliter non esset logicum quod dicitur: quia res in se condiderata, non secundum quod stat sub dictione, non ad logicum, sed ad Philosophum pertinet. 50

As for the word, the nature or essence (substantia) signified by such a

47. De praedicamentis, tract. 1, cap. 3 (Paris, vol. 1, p. 155): "therefore, Aristotle defines it in the following way: those are said [to be] univocal that have their name in common, and when the account or definition of the substance corresponding to that name is the same."

48. See Boethius, In Categorias Aristotelis, 164B-167A.

49. De praedicamentis, tract. 1, cap. 3 (Paris, vol. 1, p. 155B). Again, Albert attributes to a word what primarily belongs to the concept that it signifies and to the way in which we know things. See Albert the Great, Super Sententiarum, I, d. 2, a. 13, ad 1 (Paris, vol. 25, p. 68A).

50. De praedicamentis, tract. 1, cap. 3 (Paris, vol. 1, p. 155B): "They are called univocal ... . so that the thing itself be refered to the action of saying and to the word, for otherwise what is said would not belong to logic. Indeed, the thing considered in itself and not in as much as it stands under the word belongs not to the logician, but to the Philosopher." 
word, and the definition 51 of that nature (ratio substantiae), they are one without qualification, simpliciter. The word is one, nihil nominans in uno quod non nominetur in altero, because the signified nature is participated in by all equally, that is, without one participating in it more than another or before another. They participate in it in one way, just as it itself is one. ${ }^{52}$ Albert then repeats Aristotle's example:

Ita quod animal nomen unius naturae notam facit quae aequaliter est in homine et bove, quae quidem natura est substantia animata sensibilis: et ideo si explicetur natura sive substantia quae dicitur per nomen ... sic explicans nomen ratio sive diffinitio erit communis aequaliter utrique: unde si quis assignet utriusque rationem, hominis scilicet et bovis, secundum hoc quod sunt animalia, hoc est, secundum naturam de qua notam facit nomen commune quod est animal, eamdem de necessitate assignabit hominis scilicet et bovis rationem diffinitivam. 53

Before going back to what Albert had previously said about equivocation and analogy, let us look at Albert's conclusion to this chapter on univocation because it confirms what we conjectured earlier when reading the $D e$ antecedentibus ad logicam: among the five properties of words listed therein ("univocation," "equivocation," "analogy," "diversivocatio," and "multivocatio"), only the first three are truly logical properties, and the others are mentioned merely out of respect for tradition:

Attendendum autem est, quod quamvis multivoca sive synonima et diversivoca non sunt de his quibus praedicabile ordinatur in linea generis, eo quod synonima respiciunt unum particulare vel speciale per diversas proprietates quae sunt in illo multis significatae nominibus: diversivoca autem, sicut diversa sunt nomina, sic diversis attribuuntur; tamen quia Avicenna ${ }^{54}$ et Algazel $^{55}$ et Joan. Damascenus ${ }^{56}$ in suis

51. Meaning by that any explanation whatsoever, and not necessarily a strict definition, by genus and specific difference. De praedicamentis, tract. 1, cap. 3 (Paris, vol. 1 , p. 155B).

52. De praedicamentis, tract. 1, cap. 3 (Paris, vol. 1, p. 155B): "so that the word animal means one nature that is found equally in man and in ox, which nature is animated substance endowed with sense perception. Therefore, if one explains the nature or the substance that is signified by that word ... the account or definition explaining that word will belong equally to each. This is why if one gives the account of each, that is to say of man and ox, in as much as they are animals, that is to say in conformity with the nature that the common word animal signifies, one will necessarily give the same definitional account of man and of ox."

53. De praedicamentis, tract. 1, cap. 3 (Paris, vol. 1, p. 156A).

54. No mention of those is made in the Latin translation of Avicenna's Logyca, which includes only Avicenna's general introduction to logic and his commentary on Porphyry's Isagoge. Would Albert, then, be referring to the following commentary on the Categories, which, we are usually told by historians, was never translated in to Latin? Or does he say so because they are mentioned in Algazel's Logica and because he knows that this treatise is merely a compendium of Avicenna's teachings?

55. Logica Algazelis, maneria prima (Lohr).

56. Dialectica, cap. 18. 
praedicamentis ponunt ista, et nos ea hic ponemus non ad necessitatem scientiae sed ad doctrinae perfectionem. Sunt igitur multivoca sive synonima, quando multa nomina uni rei attribuuntur, ut ensis, mucro, spata, gladius, vel Marcus, Tullius, Cicero: his enim nominibus idem significatur secundum diversas proprietates quae sunt in illo. Diversivoca autem sunt, quando diversa nomina diversis attribuuntur, ut lignum, homo, lapis et hujusmodi. Sed his non indigemus ad istius scientiae necessitatem, in qua (sicut in geometricis facit Euclides) non praemittimus nisi diffinitiones eorum quae requiruntur ad ordinationem praedicabilis ad unum quod est in illo ordine praedicabile sive dicibile primo, sicut est principium transcendens quod in omnibus principiis est, et sicut est generalissimum: propter primum enim oportet ponere rationem aequivocorum, propter secundum autem necessaria est univocorum ratio. 57

The study of diversivocatio and multivocatio is of little use in our quest for unity and order among the many incomplex notions that our mind naturally fashions within itself. This is particularly easy to see in the case of diversivocatio, wherein, as Albert says, many words signify many things. The way in which he justifies his disregard for multivocatio, however, is not so clear, and I must admit that I have not yet arrived at an understanding of it. I would have thought rather that he would say something like this: the logician is looking for the properties of words that manifest the way in which we conceive things; thus the fact that we can signify through many different words the one truly common nature that belongs to two or more supposita (multivocatio) is of no interest, especially since we can do so with one word ("univocation"); in fact, multivocatio seems to be more an impediment to the ordering of our thoughts than one of its principles.

57. De praedicamentis, tract. 1, cap. 3 (Paris, vol. 1, p. 157): "It must be remarked that even though multivocals or synonyms and diversivocals are not of those by which one can order a predicable in the line of a genus (because synonyms are in relation to one particular or specific [thing], through the different properties found in it that were signified by many words, whereas diversivocals are attributed to different [things] just as they are different words), yet because Avicenna, Algazel, and John of Damascus put them in their Predicaments, we too will do it, not because they are necessary to the science but in order to make a complete teaching. Therefore, there are multivocals or synonyms when many words, like ensis, mucro, spata and gladius, or Marcus, Tullius, and Cicero, are attributed to one thing. Indeed, the same thing is signified by those different words, corresponding to the different properties found in it. On the other hand, there are diversivocals when different words, like wood, man, rock, and so on, are attributed to different things. However, those are not necessary to this science. As Euclide does in his Geometry, we only establish first the definitions of what is required to the ordering of one predicable to the another one that is first in that order, as a transcendant principle that is in all principles, and as a supreme genus. For the latter we have to establish the definition of equivocals and for the former the definition of univocals was necessary." 


\section{Equivocation and Analogy}

Albert's rejection, so to speak, of diversivocatio and multivocatio might help explain a very particular feature of his teachings on equivocation, which we already encountered in his introduction to logic and which we see again in his commentary on the Categories. Unlike most commentators, he usually pays no attention to a casu aequivocatio, as Boethius and Aquinas understood it, which seems to be best exemplified in the case of the same proper name given to different children without the intelligence making any kind of link between them. ${ }^{58}$ (Albert does use the expression a casu aequivocatio but to name something else, that is, something that involves some such link.) One may rather readily assume that Albert, who likes to characterize logic as the science of those instruments by which one can go from the known to the unknown, would make these lines from Thomas Aquinas his own: quando unum de pluribus secundum puram aequivocationem praedicatur, ex uno eorum non possumus duci in cognitionem. 59

Thus, whereas a univocal word makes us know what things have in common simpliciter, and an analogous word what they have in common in some qualified way, a word that is said in a purely equivocal manner of two things does not make us know any sort of community between them. Given that for Albert the logic of the first operation is entirely devoted to unifying and putting order in our simple conceptions ${ }^{60}$ and that he disregards what does not help us achieve this goal, there could be a reason why, to the best of my knowledge, he never treats truly unintentional equivocation. ${ }^{61}$ But let us now see how he comments on Aristotle's definition of equivocation.

Albert starts by stating that Aristotle puts the definition of equivocation before that of univocation because our most common words, like "being"

58. Boethius, In Categorias Aristotelis, 166B, and Aquinas, Sententia libri Ethicorum, lib. I, lect. 7; R.-A. Gauthier, ed. (Roma: Commissio Leonina, 1969), pp. 26-27.

59. Summa contra gentiles, lib. I, cap. 33, n. 4 (Roma: Marietti, 1946): "when something is said of many [things] according to mere equivocation, we cannot proceed from it to the knowledge of them."

60. De praedicamentis, tract. 1, cap. 1 (Paris, vol. 1, p. 149A).

61. Of course, it is also possible to look for a less philosophical reason. For example, it is well known how much respect Albert the Great had for Avicenna. Some believe that Albert had at his disposal a now lost translation of Avicenna's commentary on the Categories; see M. Grignaschi, "Les traductions latines des ouvrages de la logique arabe et l'abrégé d'Alfarabi," Archives d'histoire doctrinale et littéraire du Moyen Age 39 (1972): 41-107; and more recently, de Libera, "Les sources gréco-arabes," p. 332. Now, it seems that in his account of equivocation and of its division, the Persian philosopher paid no attention to, and made no mention of, pure equivocation, that is, words with totally unrelated meanings. See I. Madkour, L'Organon d'Aristote dans le monde arabe (Paris: Vrin, 1934), pp. $61-62$. 
and "one," are not univocal but equivocal, even if in fact equivocation must be reduced to univocation as multiplicity to oneness:

Quia autem primum omnium quod praedicatur est ens, quod univoce de omnibus non praedicatur ... ideo primo de aequivocis dici oportet. Et iterum propter hoc ut sciatur quid de quo ut genus, vel species, vel differentia, vel proprium, vel accidens non praedicatur, quamvis univocum sit ante aequivocum, sicut unum ante multa: tamen secundum intentionem hujus doctrinae aequivocum est ante univocum, quia per aequivocum praedicabile reducitur ad ens et unum quod est ante omne genus. ${ }^{62}$

Then follows Aristotle's definition of equivocals: Aequivoca ergo dicuntur quorum solum nomen est commune, secundum nomen vero illud ratio substantiae est diversa. ${ }^{63}$ Albert's commentary on this definition is a good instance of his rather peculiar style: rich and dense but at the same time confused and without any form of order. By gathering what he says here and there, however, one can get the following picture of his understanding of this definition.

The first elements of Albert's explanations are the same as in the case of univocation: the plural form (aequivoca dicuntur, not aequivocum dicitur) is used because the equivocal word unifies the plurality of reality; and by saying dicunturinstead of sunt, one shows that equivocation is not a property of things in themselves, a vocibus vel dictionibus absolutae, but as named. ${ }^{64} \mathrm{But}$ there is an even stronger reason for using dicuntur in the case of equivocals: as Albert says when relating this dicuntur to the rest of the definition, equivocals are truly one in their name only and not in the nature or essence signified (esse):

Et ideo etiam additur, quod dicuntur et non sunt, quia quod est in dictione commune est eis: in esse autem quod dicitur per nomen, non est communitas secundum aequam participationem: quamvis enim aequivocum actuali multiplicitate multa dicat, tamen nihil omnium

62. De praedicamentis, tract. 1, cap. 2 (Paris, vol. 1, p. 151B): "Because the first of all to be predicated is being (which is not predicated univocally of all) . . . we must therefore speak about equivocals first. Moreover, in order to know what is not predicated of what as a genus, a species, a difference, a property or an accident, and even though univocal comes before equivocal, as one before many, in conformity with the intention of our teaching equivocal comes before univocal, because it is through equivocation that a predicable is reduced to being and one, which come before every genus."

63. De praedicamentis, tract. 1, cap. 2 (Paris, vol. 1, p. 151B): "Those are called equivocals that have only their name in common, whereas the account of the substance corresponding to that name is different."

64. De praedicamentis, tract. 1, cap. 3 (Paris, vol. 1, p. 155B). 
illorum aequa participatione participatur ab his quae in nomine significantur: propter quod aequivoca dicuntur, quia aequaliter nomen habentia, esse nominis non aequa suspiciunt participatione. ${ }^{65}$

Equivocals do not participate in an equal manner in what the word that makes them such signifies. This, however, remains quite vague, and one wonders what is meant exactly. It is only when explaining the two (principal?) modes of equivocation, namely, equivocation by analogy and equivocation by chance, that Albert becomes somewhat more precise and furnishes more examples. He does repeat Aristotle's example and applies it to this general definition, yet a certain vagueness remains:

Hoc est ergo quod dicit Aristoteles quod aequivoca dicuntur, quorum solum nomen commune est: secundum tamen illud nomen ratio substantiae diversa est, ut animal homo et quod pingitur: horum enim solum nomen (quod est animal) commune est, secundum nomen vero quod impositum est ad significandum, ratio diffinitiva substantiae significatae est diversa: si enim aliquis assignet per propriam diffinitionem quid secundum quidditatem, et esse utrumque eorum divisim sit, quo sive qua proprietate sunt dicta animalia, propriam utriusque divisim et non unam urtique communem assignabit rationem diffinitivam: de homine enim dicet, quod est animal rationale mortale, de picto autem quod est imago per similitudinem lineamentorum et coloris hominem repraesentans. ${ }^{66}$

Indeed, what does "diverse" mean? Are the definitions of the signified natures or essences always diverse, as in this example, or can it be otherwise? Even if he does not actually say so, this could be a sign that in Albert's view equivocation is not a genus, strictly speaking, and that the definition of the

65. De praedicamentis, tract. 1, cap. 2 (Paris, vol. 1, pp. 151B-152A): "Therefore, it is also added that they are called, and not that they are, because what is in the word is common to them, whereas the essence that is signified by the word is not common [to them] according to an equal participation. For even though an equivocal [word] says many [things] in act, yet nothing of all that is equally participated in by those that are signified by the word. That is why they are called equivocals, because having a word in an equal manner, they do not have the essence [signified by] the word in an equal manner."

66. De praedicamentis, tract. 1, cap. 2 (Paris, vol. 1, p. 154): "Here is, then, what Aristotle says: those are called equivocals that have only their name in common, whereas the account of the substance corresponding to that name is different, as a man and a painting are called animals, because only their name, that is to say animal, is common, whereas the definitional account of the substance signified by the word that was made signifying is different. Indeed, if one says, by a specific definition, what each of them is, seperatly, in its quiddity or essence, what is that by which or the property by which they were called animals, one will give a definitional account specific to each, and not one that would be common to both. For one will say, about man, that he is a rational mortal animal, and about the painting that it is an image that represents a man by resemblance of lines and color." 
so-called genus is purposely ambiguous and will have to be understood in different ways as one proceeds through its modes.

At this stage of his commentary, Albert the Great raises a question: how can we say that the word is the same if the definition of what is meant thereby is not? Are there not then many words? A word, says he, has two forms: a substantial form that makes it what it is (that is, a word) and another one, more accidental and susceptible of change. The signification of a word is of the second kind:

Significatio rei quae intenditur per nomen formam dat nomini. Tamen haec non sunt de intrinsecis ipsi nomini secundum quod nomen est solum, sed potius intrinseca sunt nomini litteratio talis sive compositio nominis ex littera et syllaba et accentu, quae sunt intrinseca nomini ut nomen est. Quibus jam perfectis quantum ad substantiam nominis tunc primum refert nomen ad id quo affectus est ille, sive quod concepit ille qui nomen imposuit: et ideo in aequivocis solum nomen secundum quod consistit in sono litterarum et syllabarum et accentu est commune, et absque aequa participatione alicujus rei quae importatur in nomine. ${ }^{67}$

The fact of signifying is, of course, part of the definition of a word as word, he says later, 68 but not the fact of signifying such and such a thing. The particular signification of a word is similar to a second perfection that can be changed without altering its substance.

Albert enumerates two modes of equivocation, and it is not altogether clear whether for him these are the only two. The first one is analogy:

Ex quo patet quod aequivocorum multi sunt modi sive species. 69 Sunt enim aequivoca idem quidem secundum rem, sed non aeque participantia, hoc est, per eamdem rationem de omnibus aequaliter

67. De praedicamentis, tract. 1, cap. 2 (Paris, vol. 1, p. 152A): "The signification of the thing that is intended by the word gives its form to the word. Yet, such things do not belong to what is intrinsic to the word only as a word. What is intrinsic to the word are rather such or such literation or composition of letters, syllables and accent. Once we have what belongs to the substance of the word, then the word refers first to that by which the one who imposed that word was influenced, or to what he conceives. In the case of equivocals, then, only the word in as much as it consists in the sound of letters and of syllables, and in the accent, is common, without there being some equal participation in something of the thing that is implied in the word."

68. De praedicamentis, tract. 1, cap. 2 (Paris, vol. 1, p. 154A).

69. This does not make things clearer. Speaking of modes of equivocation, Albert seems to indicate that equivocation is not something that can be divided like a true genus, that is, into true species. Does his sive species reverse this whole supposition? Not necessarily since, as he tells us in his commentary on Aristotle's Topics, "species" is not always used in a strict manner and sometimes signifies the same as "mode"; see Topica, lib. I, tract. 3, cap. 4 (Paris, vol. 2, p. 273A). 
datam, sed potius quemdam modum illius (de quo datur ratio) habentia: sicut ens dicitur aequivoce de omnibus entibus per se et in alio existentibus, eo quod per se ens solum naturae ens, alii autem quaedam modi sunt illius entis et non entia vera et principalia. Hoc modo sanum in animali, et urina, et dieta, et medicina dicitur aequivoce: quia sanum naturae est animalis: alia autem quemdam modum dicunt sanitatis, significativa et conservativa sanitatis, vel ut sanitatis perfectiva, vel aliquo alio modo qui in animali est se habentia. Si enim medicus dicitur aequivoce de eo qui perfecta (quae in ipso est) medicina operatur, et de vetula medicum imitante, et clystere quod ut instrumentum perficit operationem et actum medici . . . : sic etiam ens et unum dicuntur aequivoce, eo quod ens et unum primo est id quod per se est ens et unum: alia autem dicuntur ens et unum, quia ad id sicut ad subjectum aliquo modo entitatis referuntur, vel sicut mensura illius, vel sicut dispositio, vel sicut respectus, vel aliquo alio modo, quae sunt in illo sicut in subjecto. Et hic quidem modus vocatur multiplex 70 dictum secundum analogiam, sive proportionem ad unum quod principaliter in nomine significatur. ${ }^{71}$

When reading this text for the first time and keeping in mind the explanation Albert has previously given in his introduction to logic, one can notice two differences: the definition of analogy is expressed in apparently somewhat different terms, and what were clearly presented as the three modes of analogy (ad unum, ab uno, et in uno) seem here merely to play the role of examples.

The definition is, of course, made ambiguous by the use of ratio, a word that has given nightmares to more than one reader in medieval philosophy.

70. I read multipliciter instead of multiplex.

71. De praedicamentis, tract. 1, cap. 2 (Paris, vol. 1, pp. 152B-153A): "Starting from that it is clear that there are many modes or species of equivocals. Some equivocals are the same as to the thing, but do not participate in it in an equal manner, that is to say according to a same account given of all. They rather have a certain mode of that of which the account is given. For example, being is said equivocally of all beings, existing by themselves or in another, because being by itself is the only being of nature, whereas the other ones are its modes and not true and principal beings. Thus, healthy is said equivocally of animal, urine, diet, and medication, because the natural health is the one of the animal, whereas the other ones mean modes of it (as what signifies or keeps health, or as what completes health, or as what is related in any way to the health of the animal). Indeed, if medicus is said equivocally of the one in conformity with the perfect medical art that is found in him, of the old woman who imitates him, and of the syringe that, as a perfect instrument, completes his operation and act . . . then being and one are also said equivocally, because a being and what is one are first of all what is, by itself, a being and one, whereas others are called beings and one because they relate to it by some mode of entity as to a subject (whether as its measure, its disposition, its relation, or as what is in it as in a subject in any other way). This mode [of equivocation] is called a [word] said in many ways by analogy or proportion to something one that is principally signified in the word." 
If, as it seems to me, we take it here to mean something like a definition (in a loose sense, that is, not necessarily by means of a true genus and a true difference), then Albert's text would mean something quite similar to that which he has said in his introduction to logic. Analogous things, indeed, are those that participate in some one essence or nature (idem secundum rem) but not equally (non aeque); that is, they do not posses that nature in such a way that the definition of what is meant by their common name would be exactly the same in each case (hoc est non per eamdem rationem de omnibus aequaliter datam), and they have only a certain mode of what can be defined (sed potius quemdam modum illius de quo datur ratio habentia). This "what can be defined" is, I believe, the one and same nature that is understood according to one definition each time.

If we look at Albert's examples, we can see how this definition (which, notwithstanding appearances, is basically the same as the one in the introduction to logic) applies to particular cases. In the analogy of the word "healthy," one nature-namely, health-always defined in the same way, is part of the definition of what is meant in each of its uses; however, the different healthy things do not relate to it in the same way: one has health, another signifies health, another causes health, and so on. This shows us how for Albert the Great, analogy can be reduced to univocation because, indeed, some kind of univocation is here involved: there is one nature, health, that is always defined in the same way. The difference lies in this: whereas things named univocally all relate in the same way to some one nature defined by one definition, things named analogously relate differently to some such nature or, in Albert's words, have different modes of it.

There is an expression often found in Albert's descriptions of analogy 72 but which, for some reason, is absent here: per prius et posterius. He mentions it twice, however, in his commentary on Aristotle's definition of univocals, as in this short paragraph about the one nature implied in univocation: Haec enim natura in omnibus illis est una, et non per prius et posterius participata: propter quod nomen tale simpliciter commune est omnibus illis, nihil nominans in uno quod non nominetur in altero. ${ }^{73}$ This is a clear allusion to what happens in the case of analogy and what must be excluded from univocation. But how is the expression "according to before and after" to be taken in the case of an analogous word? Logically speaking, it means the order according to which the things named analogously are named (and hence known), or the order in which our intelligence relates that univocal nature that is always present in analogy to diverse things. As Albert says about the word medicus, omnia autem haec medici accipiunt nomen per univocationem ad unum medicum, qui vere medicus est: secundum tamen diversos modos ad actum illum referuntur. ${ }^{74}$

72. See, for example, the analogy of the word "universal" within the Isagoge: Super Porphyrium De V universalibus, tract. 2, cap. 1 (Paris, vol. 1, p. 18A).

73. De praedicamentis, tract. 1, cap. 3 (Paris, vol. 1, p. 155B): "Indeed, that nature is the same in all, and is not participated in according to before and after. This is why such a word is simply common to all, since it names nothing in one that it does not name in another." 
Yet when we venture outside of Albert's logic, and above all into his metaphysical and theological works, the anteriority and posteriority of analogous words will not always be considered in terms of the way in which we know things but sometimes in terms of the way things exist, independently of our knowledge. This will have to be kept in mind by anyone willing to give a truly complete account of Albert's doctrine on analogy.

The second mode of equivocation given by Albert the Great, with which we end our brief and introductory consideration of the analogy of words, opens the door to a plethora of questions, as we now see. It is defined by him as follows:

Alius autem modus est aequivocorum, quae Boëtius vocat a casu et fortuna aequivoca, ${ }^{75}$ quando scilicet idem nomen casu et fortuna diversis imponitur, quorum substantia cul nomen imponitur, non est una nec unius respicientis ad unum, vel etiam diversorum respicientium ad unum: sed tamen qualitas qua nomen illud diversis imponitur, per similitudinem translationis est una, ut canis quod imponitur latrabili, et marino, 76 et coelesti: et eorum substantia cui nomen imponitur non est una, sed diversa genere proximo et specie. Et proprietas sive qualitas a qua nomen imponitur, non nisi per similitudinem translationis est una. Verbi gratia mordax esse, quod convenit omni quod dentibus mordet: per translationem autem convenit ei quod mordet qualitate et respectu nocivo. 77

This definition repeats that in Albert's introduction to logic but adds a few more elements. He repeats what he said earlier, that an equivocal word is imposed on diverse things because of some property found in all of them, but that property is defined in a different way in each case. How can he

74. Ethica, lib. I, tract. 5, cap. 17 (Paris, vol. 7, p. 81B): “All those medici receive their name by univocation in respect to the true medicus, though they refer to this act in different ways"; my emphasis.

75. Once again, I do not know why he keeps using Boethius's expression, in spite of rejecting the meaning that the latter had given to it, and I can hardly believe that this is mere misunderstanding. Indeed, and as Albert's explanation itself shows, a barking dog and a dogfish are thus named a consilio. See Boethius, In Categorias Aristotelis, 166B.

76. The text gives marinis.

77. De praedicamentis, tract. 1, cap. 2 (Paris, vol. 1, p. 153A): "There is another mode of equivocals, that Boethius calls equivocals by chance and fortune, that is to say when the same word is imposed by chance and fortune on different [things], and when their substance (on which the word is imposed) does not have the unity of one [thing] in relation to another one, nor that of many [things] in relation to another one. The quality through which the word is imposed on different [things] is rather one by metaphorical similitude. For example, dog, that is imposed on the one that barks, on the one that lives in the sea, and on the celestial one. Their substance, on which the word is imposed, is not one, but generically and specifically different. The property or quality starting from which the word is imposed is one only according to a metaphorical unity. Thus, to bite, which belongs to whatever bites with teeth, metaphorically belongs to what bites because of a quality or a nocive relationship." 
claim, then, that even in equivocation some kind of unity, other than merely nominal, is involved? Surely, we have to posit some unity if we are to explain why men decided to apply the same word to different things:

Adhuc autem quia in aequivoco manet eadem forma quae est actus significandi ad placitum instituentis secundum respectus ad aliquid rei signatae, quod ratio fuit instituendi signum id, de facili patet, quod in omni aequivoco, sicut diximus, aliquid est de univoco per quod aequivocum ad univocum ${ }^{78}$ habet reduci: unum enim signum diversis ad significandum ponentes, necesse est ad aliquid unum respicere, quod aliquo modo est in illis, quae substantia et ratione substantiae diversa sunt. 79

It might be that in his De praedicamentis, Albert the Great somehow relates equivocation a casu and analogy or similitude of proportionality. The way in which he describes the latter in his nonlogical treatises is indeed very similar to the accounts of equivocation we have just examined. See for example this passage, from his Super Dionysii epistulas, about the word "lion" when said of God:

Quamvis huiusmodi symbola occultent veritatem, inquantum sunt sensibilia quaedam, tamen inquantum sunt relata ad spiritualia, manifestant ea. Referuntur autem symbola sensibilium in spiritualia per similitudinis inspectionem ... non quae sit secundum participationem eiusdem qualitatis, quia omnino differentes sunt qualitates corporalium et spiritualium, neque per proportionem ad illa, qui improportionabilia sunt, nec eis quantitas eiusdem rationis, sed per similitudinem proportionalitatis, in qua oportet quattuor facere, scilicet accipere proprietatem rei sensibilis et comparare eam ad suum actum et similem comparationem invenire proprietatis rei spiritualis ad suum actum, sicut proprietas leonis est animositas, per quam vincit omnia animalia sibi resistentia; similiter deus sua virtute superbos et resistentes sibi deicit. Non est igitur neque virtus neque actus victoriae

78. I read univocum instead of unicum, given by the text.

79. De praedicamentis, tract. 1, cap. 2 (Paris, vol. 1, pp. 154B-155A): "Moreover, since in the case of the equivocal there remains a same form, which is the act of signifying by convention of the one instituting in respect to something of the signified thing, one can easily see that in every equivocal, as we said, there is some univocation by which the equivocal must be reduced to the univocal. When we impose one sign on many [things] to signify them, there must necessarily be some relation to something one that is in some way in those that are different in their substance and in their substantial account." Again, one cannot help wondering why Albert uses Boethius's expression (aequivocatio a casu) if the different meanings were consciously and purposely given to the same name. He is certainly using casus and fortuna in an equivocal manner. 
eiusdem rationis in leone et deo, sed tantum comparatio, quia sicut se habet virtus leonis ad suam victoriam, ita virtus divina ad suam. Et haec est similitudo proportionalitatis, quae semper est ad minus inter quattuor vel re vel ratione, quando uno utitur ut duobus, sicut si dicatur: sicut se habet quattuor ad duo, ita sex ad tria, vel: sicut sex ad quattuor, ita novem ad sex. 80

The word "lion" is applied to a savanna animal and to God because of some virtus found in both. However, this virtus is evidently not defined in the same manner, and it is one in a very qualified way: just as the lion's virtus is compared to its act, so, too, is God's virtus to its act. Hence, they may be given the same word.

In his second commentary on the Ethics, Albert explains the equivocation of canis in quite similar terms:

Quamvis enim aequivocum ad univocum reducatur, non tamen ita reducitur quod unio sit: sed ad unum reducitur quod secundum proportionem commune est, sicut est mordax esse vel nocivum, ad quod respexerunt qui nomen imposuerunt, unum nomen dantes coelesti et marino et latrabili quod est canis. Mordax tamen esse dentibus latrabili convenit et marino . . . coelesti autem non convenit nisi per nocumenti immissionem: et haec non conveniunt nisi in communi effectu, qui est illatio nocumenti. 81

80. Super Dionysii epistulas, 9 (Monasterii Westfalorum: In aedibus Ashendorff, 1978), vol. 37, 2, p. 530, 1.4-28: "Even though such symbols hide the truth in as much as they are objects of sense perception, yet in as much as they are in relation to spiritual [things] they manifest them. Now, symbols of sensible [things] are related to spiritual [things] when we see some similitude . . . not the kind of similitude that implies a participation in a same quality (since qualities of sensible [things] and spiritual [things] are completely different), nor one by proportion to [things] that cannot be proportioned and that do not have a quantity according to the same account, but by similitude of proportionality. In such a similitude, there are four [things] to do: grasp the property of the sensible thing and compare it to its act, and find an similar relationship between a property of the spiritual thing to its act. For example, valor is the property of the lion by which it conquers the animals that resist it; in a similar way, God, by His power, hurls down those who are proud and who resist Him. Now, this power and this act of victory are not found in God and in the lion according to the same account; [what is found in both is] only the comparison: the power of the lion is to its victory what the divine power is to His. And such is similitude of proportionality, which always takes place between at least four [things], whether in reality or in reason (that is to say when one is used as two). For example: four is to two what six is to three, or six is to four what nine is to six."

81. Ethica, lib. I, trac. 5, cap. 17 (Paris, vol. 7, p. 81B): "Indeed, even though equivocal is reduced to univocal, yet this reduction does not imply that there is in 
It seems that for Albert, similitude of proportionality is not an analogy in the narrowest sense of the word. Analogia stricte accepta, indeed, involves different relations to some one nature, whereas similitude of proportionality cannot be said to imply an ad unum in the same way. ${ }^{82}$ If true analogy ad unum declines from, and is like an imperfect imitation of, univocation, the so-called analogy of proportionality is one step further from univocation. 83 In his commentary on Dionysius's Divine names, Albert's mode of expression shows that for him analogy ad unum and analogy secundum communam proportionem are not species of a genus; rather they imply two different meanings of the word "analogy":

Deus proprie non potest connumerari alicui rei, quia non est aliquid sibi commune et creaturis neque per speciem neque per genus neque per analogiam, quia in communitate generis et speciei est aliquid unum in pluribus eodem modo per diversas differentias vel per diversas partes materiae, in communitate autem analogiae est aliquid unum in pluribus diversis modis, sicut ens in substantia et accidente et sanum in homine et urina. Sed non potest aliquid esse in deo et in quodam altero, qui oporteret, quod contraheretur in utroque, et sic deus esset compositus et esset in ipso universale et particulare; et ideo non est in deo aliqua dictarum communitatum ad aliquid aliud; sed est tamen aliquis modus analogiae ipsius and creaturas, non quod idem sit in utroque, sed quia similitudo eius quod est in deo, invenitur in creaturis secundum suam virtutem. ${ }^{84}$

equivocation] a [true] unity: it is reduced to something one that is common by proportion. For example, to bite or to be nocive (which is what those imposing the word were looking at, when they used the same word $d o g$ to name the celestial one, the sea one and the one that barks): the one that barks and the sea one are nocive because of their teeth, whereas the celestial one is so because it brings harmfulness. What they have in common is only their effect, which is to bring harmfulness"; my emphasis in the Latin text. Of course, the explanation of this particular case of equivocation is likely to be historically false: the sea fish and the star were more probably called dogs because they look like our familiar animal. The analogy here involved is closer to the example given by Aristotle: the painted man is called an animal because it looks like a real animal.

82. This is why, I think, Albert does not "seem to be interested in proportionality" (Ashworth, "Analogy and Equivocation," p. 123), at least in logic.

83. See De praedicamentis, tract. 1, cap. 2 (Paris, vol. 1, p. 154A), where Albert says that equivocation has many modes, but analogy ad unum occupies the first place, being closer to univocation.

84. Super Dionysium De divinis nominibus, cap. 13 (Monasterii Westfalorum: In aedibus Ashendorff, 1972), vol. 37, 1, p. 445: "Properly speaking, there is no common measure between God and something else, because there is nothing common to Him and to a creature, either generically, specifically or analogically common. Indeed, in the generic and specific commonnesses there is something one that exist in the same way in many [things] [and that is differenciated] through differences or through different material parts, whereas in the analogical common- 
A particular analogy of proportionality can be reduced to one of the three modes of analogy ad unum. For example, if it involves subjects, it can be reduced to analogy ad unum subiectum, ${ }^{85}$ or if it involves ends, to analogy ad unam finem. ${ }^{86}$

Albert's general description of equivocation a casu in his De praedicamentis not only evokes what he says elsewhere about that imitation of analogy called analogy of proportionality but also refers to it by these very words: substantia cui nomen imponitur non est una nec unius respicientis ad unum vel etiam diversorum respicientium ad unum. ${ }^{87}$ It is thus difficult not to think, at least at first sight, that the unity implied in such equivocation is the one found in the analogy diversorum ad diversa, that is, the analogy of proportionality. 88

It is also interesting to note, before putting an end to our consideration, that metaphor (similitudo translationis) is also mentioned in this text. Three things are then more or less equated: equivocation a casu, analogy of proportionality, and metaphor. Yet, I do not think that one may infer that for Albert these three are exactly the same, despite all appearances. It might well be that Albert is merely putting together, in his own awkward and confused way, everything that falls short of univocation and of what he considers to be analogy, properly speaking. ${ }^{89}$ However, only a thorough examination of his teachings will show the exact relations that are to be found between those very imperfect modes of unity that must be excluded from a study of the categories.

ness there is something one found in many [things] in many ways, as being in substance and accident, or healthy in man and urine. But there cannot be something in God and in something else that should be contracted in each of them, since thus God would be composited and there would be in him a universal and a particular. Therefore, there is not in God any of the aforesaid commonnesses with something else. However, there is some mode of analogy between Him and the creatures, not because there a same thing in each of them, but because a similitude of what is in God is to be found in creatures according to their power."

85. Ethica, lib. I, tract. 5, cap. 17 (Paris, vol. 7, p. 82A).

86. De bono, tract. 1, q. 1, a. 4 (Monasterii Westfalorum: In aedibus Ashendorff, 1951), vol. 28, p. 10, 1l. 1-34.

87. De praedicamentis, tract. 1, cap. 2 (Paris, vol. 1, p. 153A).

88. For an enumeration of those three, see Topica, lib. II, tract. 2, cap. 6 (Paris, vol. 2, pp. 323B-324A); and Summa theologiae, lib. I, tract. 3, q. 15, cap. 2, pars. I (Monasterii Westfalorum: In aedibus Ashendorff, 1978), vol. 34, p. 61.

89. For example, Albert explicitly opposes the multiplicity of canis to similitudo translationis in De sophisticis elenchis, lib. I, tract. 2, cap. 5 (Paris, vol. 2, p. 544A), and to analogy of proportionality in his two commentaries on the Nicomachean Ethics: Super Ethica, lib. I, lect. 6 (Monasterii Westfalorum: In aedibus Ashendorff, 1968), vol. 14, p. 30, ll. 1-23, and Ethica, lib. I, tract. 5, cap. 17 (Paris, vol. 7, pp. 81B-82A). 


\section{CONCLUSION}

Even if our brief consideration has not allowed us to draw a clear and determinate picture of Albert the Great's doctrine of analogy, it does allow us to bring to light some of its elements. First, the study of analogous words, if analyzed in terms of their meanings and not in terms of the foundations that those meanings have in reality, belongs to logic. Second, this study takes place when the logician determines, through the consideration of vocal sounds that signify by convention, the way in which our intelligence unites the multiplicity of things; this unification is carried out by means of univocation; by means of analogy, strictly speaking; or by some other means. Third, "analogy," even within the limits of the logical study of the first operation, is probably not a univocal word itself. Finally, the less perfect mode of analogy, that is, analogy of proportionality, may be somehow related to equivocation a casu and metaphor, at least as all three are opposed to true analogy. This relation, however, remains surrounded by much obscurity. 